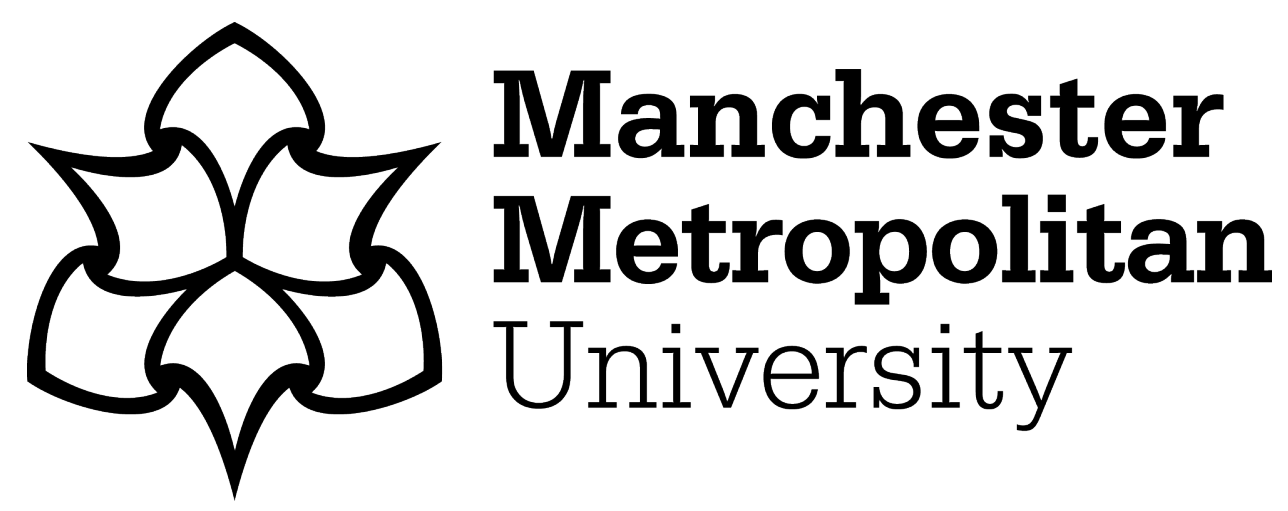

Stobart, Jon and Prytz, C (2018) Comfort in English and Swedish country houses, c.1760-1820. Social History, 43 (2). pp. 234-258. ISSN 0307-1022

Downloaded from: https://e-space.mmu.ac.uk/619371/

Version: Accepted Version

Publisher: Taylor \& Francis (Routledge)

DOI: https://doi.org/10.1080/03071022.2018.1426279

Please cite the published version 


\section{Comfort in English and Swedish country houses, c.1760-1820}

Jon Stobart and Cristina Prytz

\section{Abstract}

Comfort as an idea and ideal has attracted growing interest, especially in an AngloAmerican context. Much of the discussion has centred either on improvements in physical comfort, not least through new technologies, or on emotional comfort and the social construction of the home. This paper brings together these ideas in a comparative analysis of English and Swedish landowners. It draws on a range of correspondence to uncover more about the ways in which members of the elite themselves conceived and achieved comfort in very different geographical, economic and cultural contexts. Whilst 'English comfort' became widespread as an idealisation of elite lifestyles by the early nineteenth century, both in Sweden and elsewhere, we argue that many of its social and physical imperatives were commonplace much earlier. This involved shared concerns with warmth and airiness, and the ways in which these were linked to health and wellbeing, but also with the construction of appropriate social settings. And yet it was the emotional and non-material dimensions of comfort that dominated the correspondence in both countries: a concern with family and with home as a place defined by relationships with people rather than things.

\section{Key words}

comfort, country house, emotions, home, family 


\section{Comfort in English and Swedish country houses, c.1760-1820}

Archerfield is 'a most excellent [house] ... all is new and nicely furnished in the most fashionable manner. It wants nothing but more furniture for the middle of rooms. I mean all is set out in order, no comfortable tables to write or read at; it looks like a fine London house prepared for company; quite a contrast to the delightful gallery at Dalkeith, where you can settle yourself in any corner'. (Lady Louisa Stuart, 1799). ${ }^{1}$

In this area [Devonshire] many beautiful country houses can be found. An English country house, in its velvet-green settings and with white sandy paths winding along under lush trees, gives the most pleasant image of English Comfort. (Erik Gustaf Geijer, 1810).²

As these two quotations make clear, comfort was an important idea for country house owners and visitors in the later eighteenth and early nineteenth centuries, both in England (where such ideas are often placed) and beyond, in other parts of Europe. It was something that Swedes noted when visiting England and which they specifically associated with English modes of living; as we shall see, however, they also sought to create comfort in their own homes. But what did they and their English counterparts mean by comfort; did they conceive it in the same way and give it the same material forms? 
In an Anglo-American context, historians of the country house and domestic materiality have placed great emphasis on the importance of physical comfort as a defining feature of the later eighteenth-century home. ${ }^{3}$ Making the house 'comfortable' thus involved the introduction of an array of different and especially upholstered furniture, together with a range of new technologies, many of them to do with making houses warmer, lighter and better ventilated. ${ }^{4}$ More profoundly, perhaps, John Crowley argues that this functionalism was matched by a fundamental shift in mind-set as comfort became a key goal for elite and middling householders by the closing decades of the century. ${ }^{5}$ This can be seen as part of a longer term process in which growing physical comfort signalled material and societal progress, and - more debatably perhaps - that it helped to defuse luxury debates by offering a more morally-neutral language of comfort and convenience. ${ }^{6}$ Indeed, Marie Odile-Bernez suggests that it allowed contemporaries to critique foreign and especially French luxury, along with its overtones of waste and inequality, with virtuous English comfort, available to all as a consequence of economic and social development. ${ }^{7}$

As Lady Louisa Stuart's comment makes clear, however, comfort was more than simply a way of making luxury socially acceptable. It was a more subtle and multifaceted concept, closely linked to the idea of informality and ease. This is an idea that ties in with Mark Girouard's characterisation of the later eighteenth century as marking the rise of the 'informal house' and that John Cornforth explores through the growing plethora of interior domestic paintings produced from the 1810 s onwards. For both, the country house became more a place to live, the ideal of the Great House being replaced by that of the villa in terms of scale, organisation of rooms and arrangements of furniture. ${ }^{8}$ This linking of informality and physical comfort has a longer history, Joan DeJean finding abundant evidence of relaxed seating and clothing in early eighteenth- 
century Paris. ${ }^{9}$ In England, it was idealised in the early nineteenth century in the genteel and picturesque cottage. So, in Jane Austen's Sense and Sensibility, Robert Ferrars declares that: 'I am excessively fond of a cottage; there is always so much comfort, so much elegance about them'.10 This was not merely a sentimentailisation of the picturesque and rustic. Ferrars continued that, 'if I had money to spare, I should buy a little land and build myself within a short distance of London, where I might drive myself down at any time and collect a few friends about me and be happy'. In other words, this would be an escape and a place of privacy and intimacy. It is this combination which appears central to foreign perceptions and appreciation of 'English comfort'. It was a restrained and more accessible material culture and a different form of taste from the excesses of luxury. Or perhaps more correctly, it was more in step with Jan de Vries' notion of bourgeois 'new luxury', with its emphasis on inclusive sociability and restraint, than the exclusivity and excess of aristocratic 'old luxury'.11

Such arguments offer a compelling narrative of material change and cultural diffusion - part of the general spread of Anglomania that gradually spread across Europe through the late eighteenth and early nineteenth century, often at the expense of a taste for French fashions and practices. These were often seen as aristocratic and decadent in comparison with English moderation and restraint. ${ }^{12}$ Yet to reduce comfort to a set of material objects and spatial arrangements would be to miss its important mental and social dimensions. Crowley argues that one of the factors that limited the spread of physical comfort was that 'people acquired goods more often to display ... gentility than they did for purposes of personal comfort'. ${ }^{13}$ This not only overlooks the fact that many household objects could display gentility as well as affording personal comfort (clean bed linen, table forks, lighting, etc.) but also the ways in which what we might call social comfort could be derived from things that were physically 
uncomfortable. Feeling properly dressed in an itchy wig, sitting correctly on an upright chair, or entertaining in a large dining room that was difficult to keep warm could make the individual socially comfortable by conforming with social norms and acting with propriety. Mr and Mrs Bull, painted in 1747 by Arthus Devis, are dismissed by DeJean as unable to master 'the French look' (that is relaxed, almost decadent informality) because they are too stiff and formal, and too intent on display. ${ }^{14}$ However, it might be better to interpret their posture, dress and surroundings as linked to this different matrix of comfort.

More importantly, older meanings of comfort were by no means swept away in a rush to embrace new visceral experiences. Jane Austen may have written about the comfort and elegance of a cottage, but she most often used comfort to refer to emotions and expectations rather than physical attributes, as did Elizabeth Gaskell in the middle decades of the nineteenth century. ${ }^{15}$ Comfort meant consolation received in times of trouble, the enjoyment of social interaction, emotional support of family and friends, and, most especially, a contented marriage. The satirical print Comforts of Matrimony A Smoky House and Scolding Wife (1790) makes as much of the emotional as the physical discomfort of the situation. ${ }^{16}$ Comfort might thus derive from people as well as goods, and the two could be combined in the sentimental attachment held by particular objects. Maxine Berg notes this kind of attachment in her analysis of female will-makers and their habit of bequeathing items of sentimental value to female friends and relations. ${ }^{17}$ More recently Judith Lewis, Amanda Vickery and Helen Metcalfe have shown how emotional attachment with specific objects, often old or with particular familial associations, was central in the ways that women, but also men, made houses into homes. ${ }^{18}$ In this, they pick up on much older arguments, by Witold Rybcynski and others, concerning the ways in which home was a place of emotional well-being and 
belonging; it was associated with family, intimacy and personal attachment, all of which could be symbolised, cemented and memorialised through material objects. ${ }^{19}$

\section{A comparative approach: England and Sweden}

Rybcynski tells the story of home through a series of set pieces, the baton of cultural leadership passing from the Dutch Republic to metropolitan France to England. This is helpful to outlining the key characteristics of home in a particular age, but much more can be gained by bringing countries and domestic comfort into comparative perspective. As we noted earlier, contemporaries saw important distinctions between French and English taste and the extent to which they were aligned with notions of domestic comfort. Comparisons often highlighted shortcomings in one or the other, English commentators being increasingly critical of the showiness of the French, which came at the expense of contentment and comfort. ${ }^{20}$ Rather than re-examine these two rival systems, we turn instead to England and Sweden, focusing on the period c.17601820, a time by which many of the material changes discussed by Crowley and others were in place and when the English country house was established as the archetype of polite, informal and tasteful living. Our purpose is to assess the meaning and manifestation of comfort in two very different social, economic and geographical contexts.

The character, wealth and political influence of the English aristocracy has been discussed in great detail over the years, but the Swedish nobility is perhaps less familiar to the Anglophone world. ${ }^{21}$ As in England, the titled nobility, most of whom were Greve, (counts) and Friherre (barons), were a numerically small aristocracy comprising less than 1 per cent of the population. Together with a rather larger group of untitled 
nobility (about 4 per cent of the population), they formed one of four estates which constituted the Swedish Riksdag. This 'fourth estate' was especially influential after 1719 when the king's power was circumscribed after almost 40 years of absolutism, although there remained deep divisions between titled and untitled, and between new and old families. ${ }^{22}$ Unlike England, all children inherited their father's title and a share of his property, sons receiving an even share and daughters half a son's share of realestate (unless their parents made special arrangements). ${ }^{23}$ However, it was the oldest son who usually inherited the main family manor and represented the family politically in the Riksdag. For much of the seventeenth and eighteenth century Sweden was politically and culturally aligned with France. Many Swedish nobles served in the French army and the elite traditionally looked to French taste, fashion and luxury goods; many spoke and wrote their personal letters in French. ${ }^{24}$ It was only in the later eighteenth century that Sweden, like other countries, came under sway of English taste, although English goods - from scientific instruments to furniture - were imported in growing quantities throughout the eighteenth century.

By focusing on Sweden and England, we therefore seek to assess how elites in very different contexts conceived comfort; the extent to which they prioritised similar objects, relationships or emotions, and the ways in which these were expressed in and through the home. More specifically, we explore the extent to which behaviour in relation to comfort can be viewed as emulative. Did the Swedish elite adopt practices seen elsewhere - in a more powerful country that was rising to economic and cultural prominence in Europe - or is comfort something which developed locally?

To answer these questions, we draw on a range of sources. Illustrations and inventories, which take a similar format and survive in good numbers in both England 
and Sweden, tell us much about how the materiality of comfort was written into the furnishing the country house and how this varied over time and space. Correspondence reveals something of how people felt about comfort and what they understood and meant by the word. However, such sources bring particular challenges in this kind of comparative study, most particularly in the meaning of specific words to contemporaries and how they might best be translated today. Through the eighteenth century, there was no direct equivalent for 'comfort' in Swedish; like many European countries, Swedes simply imported the English word in the early nineteenth century, turning it into the word komfort. ${ }^{25}$ Words predating comfort in Swedish include bekvämlighet, välbefinande, trivsel, skön. ${ }^{26}$ These words were, and are, used as synonyms to comfort, but often with a slightly different set of connotations. ${ }^{27}$ When Erik Gustaf Geijer wrote home to his family in 1809 he commented on the pleasurable evenings in front of the fireplace. Comfort, he wrote, was the most common topic after politics; 'it is, I might say, a dedication to contemplate (a reverence of) all human prosperity, down to its smallest parts'. ${ }^{28}$ In his diary he adds how the word comfort could be used in relation to 'the advantage of a house and specific devices inside it; the utility and excellence of cattle breeding; the heat of their "fireside"; accommodation for travellers in specific public carriages and in "Taverns", and more'. ${ }^{29}$ Through the second half of the nineteenth century, komfort became primarily associated with material objects; to express the support, solace or joy found in family relations, stöd and tröst were used instead. ${ }^{30}$

We need to be mindful of these complexities of language and the nuanced meanings of different synonyms. However, addressing these issues and exploring Swedish correspondence shines a light on the appearance and context of comfort in English letters: which of a range of subtly different meanings did they wish to convey? 
Our comparative perspective thus helps us to move beyond cultural and social specificities and assess something of the 'universality' of ideas about comfort. Given such a broad ambition, our analysis cannot be comprehensive; when discussing physical comfort, for example, we focus on warmth and cleanliness, but say little about changing styles of furniture or lighting. Nonetheless, balancing physical and emotional aspects of comfort we can offer new insights into everyday domesticity in the country house, the construction of meaning in elite domestic environments and the importance of home as an emotional construct.

\section{Physical comfort: heat, air and cleanliness}

The fireplace has always been a source of physical comfort, especially in large houses which could be perishingly cold. ${ }^{31}$ It was central to the ways in which Richard Aldworth Griffin conceived comfort at Audley End in Essex in the 1810s, where it was combined with soft furnishings to create a pleasant living environment. He noted in a letter to a friend that: 'We lived remarkably comfortable, dining \& sitting in the Eating room where we had a capital fire with Carpet \& curtains. ${ }^{32}$ Unsurprisingly, the cold was an even more pressing issue in Sweden. In the winter of 1776-77, Brita (Horn) Ekeblad wrote from the family home of Stola in Skaraborg to her husband, Count Claes Julius Ekeblad, who was in Stockholm in service of King Gustav III, complaining that her chamber was so cold that she could hardly hold on to her pen. ${ }^{33}$ Later in the same year, she wrote again, detailing changes that she was making to the house, which included changing some of the windows and doors. She doubted her efforts would be enough to make the house much warmer, but stated that 'you have do what you can'. ${ }^{34}$ 
Doing what you can often involved deploying new technologies. In England this often involved installing register stoves with a shallow hearth, widely bevelled sides and adjustable flues - a style famously associated with Benjamin Thompson, Count Rumford. These attracted considerable attention from contemporaries as well as historians such as John Crowley, Marilyn Palmer and others. In 1800, James Gillray produced an etching entitled 'The Comforts of a Rumford Stove' which showed Benjamin Thompson, Count Rumford, standing with his back to the fire and enjoying the warmth provided. Charles Williams's 1801 version, 'Luxury, or the Comforts of a Rumford Stove' satirises Gilray by replacing Thompson with a young woman in a décolleté negligee raised to leave her bottom naked; the enjoyment is more illicit and risqué, but real nonetheless. ${ }^{35}$ Given the evident attraction and cultural currency of these improved fire grates, it is significant that such stoves were being installed in many English country houses. In his refurbishment of Stoneleigh Abbey in the early 1760s, Edward, fifth Lord Leigh, kept the earlier Bath stoves in most of the principal rooms, but installed 'moveable stoves' in the drawing room and New Rooms. These were probably register stoves. ${ }^{36}$ Thirty years later, Elizabeth Dryden and her husband, Sir John Turner Dryden made similar improvements to Canons Ashby in Northamptonshire. Elizabeth's Breakfast Closet was heated by a 'fluted pillar stove with stand' and her Sitting Room had a 'Rumford grate'. The room was made cosier still by the green baize that covered the door and the Kidderminster carpet on the floor. ${ }^{37}$ Here, as in the Welsh households studied by Wilson, we see the prestige of new technology underpinning the attraction of a warmer domestic environment. ${ }^{38}$

A very different form of heating technology was deployed in Sweden: the freestanding tile stove (see Figure 1): a tiled covered masonry construction which stores heat from burning wood. The heat radiates for a long time and at a fairly constant 
temperature, making the tiled stove in effect a storage heater. These were a common feature in Swedish houses from the seventeenth century, but largely absent from those in England. There were again technical improvements; a full generation before Rumford, changes were made in the 1760s: the flue channels were made more complex, keeping the heat and the smoke inside the stove longer, and improvements were also made to refine control of the amount of air going in and out of the stove (which saved fuel). ${ }^{39}$ At Stola, one of the first acts of Claes Julius Ekeblad when he gained control of the house in 1775 was to install new stoves in the library and in the bedroom of his wife, Brita. The couple went on to have several other stoves rebuilt with more efficient or fashionable models, although in the formal dining room they chose to retain the fireplace. This probably reflected the balance to be struck between an imposing focal point and source of light and a more effective and long lasting heating mechanism. At the new royal castle in central Stockholm, stoves were chosen over fireplaces, even in the formal rooms; no less than 150 tiled stoves were added to the original plans in 1754 shortly before the royal family moved in. ${ }^{40} \mathrm{~A}$ generation later, Count Axel Von Fersen was building his new house at Ljung in Östergötland. Stoves were installed in all rooms, their quality marking differences in status and function in much the same way as was seen at Stoneleigh Abbey: for the public rooms, there were ornate blue and white tiled stoves, designed by the architect and supplied by Stockholm craftsmen, whilst the servants' rooms got plainer green stoves. ${ }^{41}$ Even with an efficient stove, the Swedish winter was a challenge. Adolph Törneros, a friend of Geijer, wrote in January 1823 from the country house Sjösa in Södermanland, about how the cold in the early morning made him leave his bedchamber 'to search for warmer regions'. The fire had burned down during the night, and since the damper had not been closed, all the heat had 'returned to whence it came - the forest'. ${ }^{42}$ 
[Figure 1 about here]

We might seek explanations for the different solutions to heating a house in the relative intensity of cold faced by country house owners in England and Sweden, but tiled stoves were also found in German and French houses, especially in the salle à manger. ${ }^{43}$ In reality, the choice appears to have been cultural, though still linked with (perceived) comfort. Crowley argues that Rumford's stove was a compromise born of the reluctance of English householders to adopt free-standing stoves because of a preference for domestic space with lots of fresh air. As one commentator put it: 'nothing is more desirable than open fire-places; they perform the part of a perpetual ventilator'. ${ }^{44}$ This concern with the circulation of air was linked to health, as was the cold that fires and stoves tried to dissipate. In the freezing temperatures of the Swedish winter, Claes Julius and Brita Ekeblad regularly wrote reminding each other to keep warm. Brita was especially worried when Claes Julius and the court was visiting the old castle at Gripsholm and urged her husband to take his own bedding in case they were needed. ${ }^{45}$ She also asked her husband to take rhubarb and chincona bark (Jesuit's bark) if he had a cough. ${ }^{46}$ To make sure there was no risk of disease spreading in her house, she sent away sick servants and burned juniper in all rooms to clean the air - the smoke from juniper being held to be good for health, even though a smoking stove or fireplace was not. ${ }^{47}$ Indeed, on more than one occasion Brita reminded her husband to avoid sleeping in rooms that were smoky. ${ }^{48}$ Yet cold remained the primary concern, causing real fear and anxiety. Count Carl Gustaf Spens of Grensholm in Östergötland, (17921845), for example, worried constantly about the health of his children and his wife, Dorethea, especially after the winter of 1827 when she had fallen ill after a journey and miscarried their child. ${ }^{49}$ 
Hundreds of miles away in England and despite very different climatic conditions, a remarkably similar range of concerns was worrying Elizabeth Dryden. She wrote from Canons Ashby to her sister-in-law in London that the 'country [was] so cold and the place so damp that I was ... with the worst cold I have experienced for many years'. ${ }^{50}$ Moreover, she too was concerned about the quality and circulation of air. This went beyond the problem of smoking fires that troubled Brita Ekeblad and drove some of the technological developments traced by Crowley and others, to encompass the more general environment - an important issue in smoky London. When contemplating a permanent move to the metropolis in 1819 , she praised one house that was recommended to her because it was 'well aired'. Later in the same letter, however, she worried 'whether I can live at all in London as the air disagrees so much with me' and claimed that she lived in fear of the dreadful colds that afflicted her in town. ${ }^{51}$

Physical discomfort might therefore come as a consequence of more general environmental factors, with air, health and hygiene combining in a cocktail of concern. In this, Elizabeth Dryden was in tune with wider concerns over cleanliness and its link with physical health and social propriety. ${ }^{52}$ She expressed this in broad terms through her insistence that any London house found for her should be 'clean', but her worries were also more focused: 'I have much fear of the bugs', she declared, and 'must be at the expense I fear of a new bed as all old furniture in London is dangerous'. ${ }^{53}$ This reflected a growing distrust of second-hand bedding which, as Sara Pennell notes, was growing in the middle decades of the eighteenth century; advertisements for sales of used beds declined whilst those for a variety of insect extermination treatments grew rapidly. ${ }^{54}$ These concerns were common to English and Swedish householders. When Claes Julius Ekeblad gave away an unwanted bed in Stockholm, Brita reminded her husband that the bedding belonged to them; if the mattress, pillows and so on had been taken and used 
with the bed, she feared that they would become 'as dirty as everything else in the city'. ${ }^{55}$

In this episode, we see the same concerns about the dirt of the city and the infection of textiles expressed by Elizabeth Dryden, but Brita Ekeblad's worries about dirt and disease were underwritten by the link she made between cleanliness and status. Writing to her husband about preparations for a journey to Stockholm to be undertaken in 1779 in company with her mother-in-law and a number of servants, she was worried about their livery because 'the grey they wear now is not fit for Stockholm, they are both coarse and dirty'. ${ }^{56}$ Brita thus folds cleanliness onto respectability: the dirtiness of the servants' clothing being a threat to their good standing in society. This was a growing concern for aspiring households across eighteenth-century Europe, given added impetus in the early eighteenth century by the opportunities for washing afforded by new types of textiles; yet it tapped into older traditions of cleanliness and well-laundered linen as an expression of status at the table. ${ }^{57} \mathrm{~A}$ slightly different and arguably more modern concern with cleanliness is apparent from Elizabeth Dryden's reaction to an incident at her second husband's rooms in London. They had been entrusted to the care of a woman who had 'turned a thief and robbed the house of all the linen and everything moveable'. The expense was put at $£ 20$, but the immediate concern was that a housemaid be sent to London to 'clean it sufficient for him to sleep'.58 This cleaning no doubt involved the removal of physical dirt and perhaps the tidying of the mess left behind, but it might also be seen as an act of purification or reclamation of the domestic space after the despoilment of theft. 59

In these aspects of physical comfort we see similar concerns being shared across time and space. There were different solutions to heating the house, but the underlying 
agenda was the same: to render the house warm, smoke free and clean. Whilst there is no suggestion of imitation or emulation, both English and Swedish householders were aware that other countries had different practices and values. In England, there emerged a growing condemnation of French houses as cold and comfortless. Horace Walpole, for instance, wrote in January 1767, 'I suffered too much with the cold last year at Paris, where they have not the least idea of comfortable, but sup in stone halls with all the doors open'.60 Swedish visitors to England, meanwhile, were struck by the cold drafts that rattled through the houses in which they stayed. As the homesick Erik Gustaf Geijer wrote to his parents: 'I felt colder in my room here than I ever did under a Swedish roof. For when the cold arrives in this country, it can find its way through all doors and windows, and the Englishman can not do anything, except move closer to his small pile of glowing embers, which he calls a fire.' 61 What Swedes, Geijer included, did admire was the understated and informal domestic environment and landscapes associated with 'English comfort'. Yet to what extent did they emulate this in their own homes?

\section{Comfort and convenience: informality, entertaining and status}

As John Cornforth and others have argued, a comfortable house was one in which one could relax and enjoy company in an informal manner. This meant acquiring particular types of furniture and creating appropriate arrangements to facilitate the right kind of informality. As we saw in the opening quotation, Lady Louisa Stuart saw this in terms of tables for reading and writing, and corners in which to settle. Cornforth sees these changes as a feature of the early nineteenth century, revealed in the growing number of interior watercolours and engravings produced at this time. ${ }^{62}$ Elizabeth Dryden and Sir 
John Turner Dryden were thus in swim with their times. Elizabeth's private breakfast closet and sitting room were small and personal spaces containing fashionable rosewood and japanned furniture, and framed prints and drawings. More telling were the attempts they made in the 1790s to create settings for polite yet informal sociability in the drawing room. This contained a large oval mahogany table and twelve japanned elbow chairs and three pier tables which suggest a formal arrangement to the room; yet there were also a writing table, a satinwood work table and a card table, along with a large sofa with squabs and cushions which provided scope for small groups to gather in different parts of the room and engage in different activities. ${ }^{63}$ However, such interiors were nothing new: DeJean makes much of the informality of 'convenience furniture' and 'comfortable rooms' in early eighteenth-century Parisian houses, and similar arrangements were apparent in English country houses from mid century. ${ }^{64}$ In the 1760s, Edward Leigh was filling the Breakfast Room and Dining Parlour at Stoneleigh Abbey with a range of new furniture including two mahogany music desks, a Pembroke table with ebony inkstand, a small organ, and a mahogany box of battledores and shuttlecocks. These helped to transform the rooms from rather staid interiors, dominated by their plaid drapery, into spaces that in many ways must have resembled Humphrey Repton's idealisation of the 'modern living room' produced some 50 years later. Unfortunately, Edward appears to have seldom used the rooms for entertaining a result of his deteriorating mental health. However, after his death in 1784 , the process was continued by his sister, Mary; she added a variety of musical instruments, several board games and an even greater variety of work and reading tables, and enjoyed entertaining small groups of friends there during the summer months. ${ }^{65}$

Such changes accord with the materiality of polite but more relaxed sociability outlined by Mark Girouard and Amanda Vickery; by the third quarter of the eighteenth 
century, there had been a decisive shift to these socially comfortable settings. ${ }^{66}$ Perhaps more surprising is that many of these things were also to be found in Swedish country houses from the 1780s or even earlier, long before the term 'English comfort' had gained currency. This challenges any simply notion of cultural diffusion or social emulation. Indeed, it is possible that inspiration was drawn from elsewhere in Europe. The more intimate building style quickly spread, especially after king Gustaf III visited Italy in $1783-84$, and the court introduced many new ideas about socialising, Claes Julius Ekeblad commenting on how the Stockholm bourgeoisie was very offended by the King's new habit of dining privately with a smaller company or even retreating to the seclusion his pavilion at Haga in the outskirts of Stockholm. ${ }^{67}$ Back at Stola, the Ekeblads were concerned to make their house a suitable place to live comfortably and entertain their aristocratic friends. The main house was not very old, having been finished in 1719, and Claes Julius' parents had refurnished the interior in a then modern Rococo style in the 1750s. Despite this, when the newly weds moved in, they found that updates were needed. ${ }^{68}$ When their finances improved following the death of Claes Julius' mother in 1786, they immediately made plans to extend their house and employed an architect. His suggestion for a modern neo-classic building was 'the most charming drawing' according to Claes Julius, but the plan was never realised, initially because of war with Russia and Denmark and ultimately due to Brita's death in 1791.69 Instead, they set about transforming some rooms in line with modern ideas about socialising, perhaps most notably turning an old bedroom on the ground floor into a new, more intimate and informal dining room, complete with a beautiful green tiled stove to make it even more comfortable. ${ }^{70}$ At the same time, they started building a smaller villa a few miles from Stola, villa Järneväg (later Giacomina), situated on the outskirts of Lidköping by lake Vänern. The villa was a retreat with a small but exclusive 
library and a place to work; but it was also furnished for informal socialising, with a dining room, a parlour with soft furnishings, music instruments and board games, a small drawing-room and four bedrooms. In its intimacy and privacy, though perhaps not in its aesthetics, this echoed the idealisation of the cottage noted earlier - there were two separate houses for the servants and kitchen. ${ }^{71}$ Again, we find English and Swedish taste moving in step, a desire for the relative seclusion of the private villa growing strongly in England from the middle decades of the eighteenth century. ${ }^{72}$

At Sjösa in Södermanland, the house was continuously being improved and renovated by its owner, Baron Trolle-Löwen. In itself, this could be a rather uncomfortable experience, Adolph Törneros writing in August 1822 how he and his student (the Baron's son) arrived at Sjösa, only to find the house filled with workers and limestone dust. Many rooms were under repair, 'or rather reconstruction', and the family had fled the dust to their 'Sans Souci', a smaller house, Ånga, and its 'comfortable calm'. ${ }^{73}$ There the family and their guests entertained themselves with conversations (telling ghost-stories), reading, playing music, dining and taking long walks. ${ }^{74}$ Yet Törneros is careful to note that the restoration of Sjösa made living there 'more comfortable', not least because it prompted the 'hiring of more servants'. ${ }^{75}$

There were tensions, therefore, between the role of the country house as a place for informal sociability and as a symbol of power and status. One common solution to this - apparent across Europe - was to create different suites of rooms for different purposes. Cornforth and Girouard both detail the emergence of rooms with specific functions and therefore particular assemblages of furniture, but also the broader distinction between rooms of state and private or family rooms. ${ }^{76}$ The former served as a symbol of aristocratic status whilst drawing rooms, breakfast rooms and increasingly 
libraries served a social space. This spatial and material distinction is apparent at Stoneleigh Abbey where the two sets of rooms were set either side of a grand entrance hall: the so-called Great Apartment to the north and the Breakfast Room and Dining Parlour to the south, overlooking the river. What is particularly striking here is the way that the furniture and character of the Great Apartment remained fixed from its creation in the 1730 s through to the early nineteenth century. In contrast, and as we have already noted, the Breakfast Room and Dining Parlour were progressively changed as each owner sought to make them fit for polite and sociable entertaining. ${ }^{77}$ Such distinctions were maintained through the nineteenth century, despite some structural alterations which involved switching the main entrance to the north front and adding an additional reception area. ${ }^{78}$ The Great Apartment remained largely untouched by these changes, whilst the Breakfast Room and Dining Parlour were further updated with the addition of lamps and lustres, a range of new rosewood furniture and carpets. There was thus a distinction in the décor and stability of state and family rooms although all were on the same floor of the house - a common feature in England. In Sweden, the distinction was generally marked vertically, with formal rooms occupying their traditional location on the first floor, but the contrast in use and décor was the same. ${ }^{79}$ At Stola the first floor was touched only lightly by the changes made by Claes Julius and Brita Ekeblad; they focused their attention on making the ground floor a more comfortable, sociable environment. Something of the character of such rooms can be gained from Törneros's account of Sjösa: the company sat 'in warm rooms, away from the cloudy rainy winter, joined together around the fireplace, or on the sofa in jokes and ridicule, or in more serious conversations, or reading poetry, or huddled in the corner at the piano, and let our souls rest in the gentle tones of Eberl.' 80 These were informal 
spaces for informal socialising rather than projecting the formal status and pedigree of the owner, Baron Trolle-Löwen.

All this would appear to be taking us away from our focus on comfort, yet considerations of status were important in appraising the potential of a house to be comfortable. This is clear from Elizabeth Dryden's search for a suitable London house following the inheritance of the Canons Ashby estate by her son Henry, with whom she had a very poor relationship. In January 1819, she expressed a desire for a 'comfortable house in town', but later refined and amplified this considerably. April saw her writing to her sister-in-law, Mrs Steele, asking for her to seek out 'a moderate residence with a good garden', preferably in Gower Street. In June, she itemised her requirements as: 'a good sized House with garden \& backhouse \& stables adjoining; the House three rooms on a floor or light Closet at least ... I want also a large dining Parlour many feet long'. Comfort clearly meant a good amount of space, both inside the house and in terms of outbuildings. Indeed, she later added that a coach house and stables were 'indispensible as I mean to drive my own horses' ${ }^{81}$ At the same time, she was concerned with location, echoing the snobbishness of the Beau Monde nearly 100 years earlier identified by Hannah Greig. ${ }^{82}$ One house was rejected because it was in 'the worst part of Gower Street', but her prejudices were often framed in terms of her health: Gower Street, Conran Street and Tavistock Square were places where the air would be good - they were, of course, also desirable though not exclusive neighbourhoods. ${ }^{83}$ Significantly, there is no mention of the particular physical features that are generally seen as defining physical comfort. These may have been taken as read, but Elizabeth was clearly concerned with details - bugs, air quality, the need for a carpet for her dogs - and was happy to reject possible houses as 'much too small', suggesting that her ideals for comfortable town life involved status as well as warmth, cleanliness and sociability. 
Elizabeth never found her ideal house; nor did she move to London. Yet her search for a 'comfortable house in town' highlights the complex and often contradictory aspects of comfort that confronted the country house owner. Significantly, a remarkably similar set of concerns shaped the actions of elites in England and Sweden, both in terms of distinguishing rooms marking status from those for more informal sociability, and in the character of the latter. From our evidence, it seems clear that elements of 'English comfort' were spreading through Sweden long before they were formally identified with that label. It may be that this was simply a linguistic device for describing a way of living and a material culture already taking root in Sweden, as it was elsewhere in Europe. However, there was probably a political dimension underpinning this as Sweden was divided between the Hattar (hats) who favoured France and Mössor (caps) who leant towards England ${ }^{84}$ In this sense, identifying and favouring taste (or comfort) as English was a political statement, even if many of the practices and much of the material culture was already in place. Yet it would be a mistake to reduce an emphasis on comfort to political posturing. The Ekeblads wanted to construct intimate spaces for informal socialising because that suited their lifestyle; equally, they found comfort in other each other as well as their material lives - an emotional dimension that also parallels rather than follows developments in England.

\section{Emotional comfort: family, consolation and communication}

In the spring and summer of 1819, Elizabeth Dryden's desire for a new home is palpable. She wrote thanking Mrs Steele for her efforts in looking for a house 'which is a thing I much want and indeed cannot be comfortable without'. ${ }^{85}$ If we pause for a moment, this is a remarkable phrase. The looking forward to a desired object or 
outcome chimes with Campbell's assertion of a new consumer ethos that was emerging in the late eighteenth and early nineteenth centuries, one in which the prospect of consumption was every bit as enjoyable as the act of consumption itself. ${ }^{86}$ Moreover, we have Elizabeth suggesting that her current discomfort, which is mental rather than physical, can only be resolved by a material change. In this, she is using comfort in an older sense - in terms of emotional and spiritual well-being. Elizabeth Dryden's complaint was with her children, although she blamed their 'bad Tempers \& bad dispositions' on their father (her late husband): 'they are all complete Turners, which is saying enough'. ${ }^{87}$ Although her family troubles came to head in 1819, relationships had long been strained. In part, this arose from the difficulties in getting them properly set up in life, a problem directly caused by large debts left by her husband $-£ 10,980$ against an estate income of around $£ 2500$ per annum. ${ }^{88}$ Significantly for the discussion here, she conceived these in terms of comfort, writing to Mrs Steele in the spring of 1812 that 'I have little comfort in any of my family'. Sons were expected to have a dutiful respect of parents and a serious attitude to their responsibilities for the estate and the family name, whilst daughters carried more of the burden of emotional support. ${ }^{89}$ Yet Elizabeth, in a general tirade against her apparently malignant offspring, complained that 'my daughter [Caroline] is indeed a nuisance to me instead of a comfort, so that I cannot be very pleasantly situated'. 90

We have again dwelt on Elizabeth Dryden because she highlights the continued importance of family to emotional well-being. What Elizabeth lacked was the kind of familial comfort espoused by Sir Roger Newdigate, of Arbury Hall in Warwickshire, when writing in 1795 to the recently bereaved wife of his protégé Charles Parker. He argued that her 'little smiling brood' of five children 'will every day add more \& more joy and comfort'. ${ }^{1}$ Such sentiments can be seen in the letters of Anne Lister in the mid 
eighteenth century. Writing for news of the safe arrival of her son, who was travelling back to England from Virginia, she hoped 'in God now to Reap some Comfort for they are fine Sweet Tempered Dutiful Children'.92 They were just as clear in the letters received by Mary Brydges, a distant relative of the Leighs, in the late seventeenth century. Her mother, Elizabeth, wrote in September 1682 of the 'comfort of frequently receiving the joyfull news of my mothers, my sisters and thy own good health', whilst her sister, also called Elizabeth, signed off a letter sent the previous month by saying: 'God bless thee and make thee a comfort to my dear Mother'.93

In all these letters, comfort was conceived in terms of solace and consolation - a long-established meaning that endured through the early nineteenth century and beyond, and which is all too easy to overlook when focusing on material comfort. Indeed, this is often the dominant and most enduring aspect of comfort included in correspondence between family members. As the correspondence of Mary Brydges makes clear, emotional comfort was not the product of the sentimentalism or romanticism that emerged in the later eighteenth century. Rather, it was deep rooted in human relationships. It is unsurprising, then, that the comfort of family was just as important in Sweden, where the sentiment was captured by the words tröst or stöd which might translate as solace or support. Dorothea Spens expressed in a letter to her twin sister Gustava, written in summer 1827, how she found comfort ('tröst') in her husband's presence. Her newborn son had been unwell and kept his parents awake at night, worrying; but the coming week would be 'terribly sad' since her husband, Carl Gustaf, had to leave her alone at home for a week. ${ }^{94} \mathrm{~A}$ few years earlier, her sister Louise, residing in the very south of Sweden, wrote that 'I confess that I find great pleasure from my children's love and joy of having me at home. They, all six of them, stay close to me day and night [...] at night the oldest boys takes turns, sleeping in their 
(temporarily absent) father's bed. [...] Marie and Carl sleep on benches by the window.'95

[Figure 2 about here]

As in England, the roots of such emotional attachment ran deep. Fifty years earlier Brita and Claes Julius Ekeblad (Figure 2) wrote to each other regularly, in part a necessity because they were apart for so much of the year with Claes Julius engaged at court in Stockholm. As well as news about their respective daily routines, their letters expressed the couple's discomfort at being parted, which was almost palpable. Writing to inform his wife that he would soon be coming home, Claes Julius explained that 'God knows how I long for that moment, and above all to embrace my Brita'. ${ }^{96}$ She, in turn, answered 'I love you of all my heart, and in my mind I kiss you on your eyes, nose, lips and.... ${ }^{97} \mathrm{~A}$ few years later, and with the prospect of a prolonged absence occasioned by the need to accompany the King on his journey to Italy in 1783 , he wrote to Brita that the mere thought of being parted for such a long time made 'tears fall down' his cheeks. ${ }^{98}$ The contrast with Elizabeth Dryden's feelings for her family could not be stronger, yet both reveal the enduring importance of family as a source of emotional support and well being - of comfort. Yet emotions could also link people to goods and comfort could be channelled through material objects.

\section{Home comforts: people, places and things}

Judith Lewis makes much of the emotional significance of ordinary household objects in her analysis of the chatelaines of three substantial English houses. She demonstrates how their sentimental attachment to objects - evoking other people, places and times defined these women's relationship with the domestic environment and made houses 
into homes, an argument underwritten by Vickery's work on a wider cross section of well-to-do women. ${ }^{99}$ This process of drawing emotional comfort from things took a similar form in both England and Sweden, with nothing to suggest that practices learned in one country were taken to the other. Lewis describes how Lady Boringden created meaning and drew comfort from arranging family pictures in the library at Saltram. ${ }^{100}$ In much the same way, Mary Leigh brought together many of the portraits of family in the Breakfast Room and Dining Parlour at Stoneleigh Abbey. ${ }^{101}$ These had previously been dispersed across a number of rooms, but were primarily hung in the gallery. Placing them in the key rooms for polite sociability may have reflected a desire to underscore her status at a time when she had no formal title and no chance of passing on a title to heirs; looking down on her assembled guests from their picture frames, her ancestors could serve as reminders of the Leigh's long pedigree. Alternatively, it may simply be that, unmarried, childless and without surviving siblings, she simply wished to draw comfort from having familiar faces around her. Around the same time, Brita Ekeblad accorded particular significance to a pair of pictures painted by her father. When a friend gave them to Brita in 1780 she chose to put them up in her bedroom at Stola - a place which suggests an emotional attachment rather than the dictates of a decorative scheme or an attempt to construct a family gallery. ${ }^{102}$ Claes Julius expressed this object-person association in a different way: both husband and wife kept the letters they received and, after Brita's death, Claes Julius had them bound into three books. Binding his own letters in this way might be interpreted as standard elite practice: retaining and archiving of family papers to construct elite identity through a family archive. ${ }^{103}$ Doing the same with every letter and note written by his wife suggests a much stronger emotional bond, one that would have been felt all the more keenly given her early death, drowning in a river. It accords with Kate Smith's argument that it was 
the materiality of letters as well as the news they conveyed that drew people together in this case in time rather than space. ${ }^{104}$ It also underlines the universality of such feelings and practices - a response to basic human emotions.

Again, though, it is Elizabeth Dryden who challenges easy assumptions about the emotional importance of things. She appears less concerned with expressing emotional and familial bonds through her possessions and more interested in the practicalities of keeping the furnishings which she viewed as her own and as essential to a physically and socially comfortable life. When appraising the goods at Canons Ashby in January 1817, she noted in a memorandum that 'All the family writings which I have are in a long box bound with Hair with my Grandfathers initials, \& is sometimes in the Brown Gallery \& sometimes in the Storeroom, but ought to be in Sir Edward Drydens custody, as he has the greatest interest in them, not having myself any'. ${ }^{105}$ Although aware of their significance in constructing lineage, these were not things that held any emotional connection for Elizabeth; nor were a collection of mezzotint prints 'after the Titian Gallery (I believe now at Blenheim tho' not publicly shown)' which were pasted up in the storeroom where they had suffered water damage due to a leaking roof. The one set of items that appear to have held some special meaning for her were 'Two small Cabinet Pictures purchased by my Uncle [which] are in good preservation \& hang on each side of the best Cabinet in the Drawing Room'.106 Provenance, quality and location are all noted in what Epp and Price call an object-person biography. ${ }^{107}$ For Elizabeth, this was a rare expression of personal attachment to material objects. She certainly valued goods, but this was generally framed in terms of their utility or monetary value - a reflection, perhaps, of her difficult financial circumstances. The 1819 inventory of Canons Ashby makes a careful distinction between 'Furniture and Effects, Heirlooms of the Mansion' and 'the Property of Lady Dryden'. The former comprised older pieces and 
family portraits, whilst the latter included a wide range of new and fashionable furniture but also the stoves and grates fitted throughout the house. ${ }^{108}$

On occasions, there is a hint that Elizabeth Dryden did put special store by certain domestic objects. In 1822, when contemplating the acquisition of a seaside residence, she wrote that 'I must have a good house \& my comforts about me'. ${ }^{109}$ Yet even here there is ambivalence: these comforts may have been objects with emotional meanings, but they might also have been her dogs, mentioned with affection in the previous sentence. This reminder that comfort could be gained from living as well as inanimate objects is underpinned by Brita Ekeblad sending greetings to Claes Julius from their dogs, Thethis and Azur, and writing that they were sleeping on a cushion at her feet whilst she wrote to her absent husband.110 Pets were thus important objects of affection, both in Sweden and England; but of course the primary attachment here was between the correspondents themselves.

We have already seen something of the importance of letters in stitching together physically absent family and friends through the exchange of news about mutual friends, hopes for the future or memories of the past; the chance to bear one's soul or vent one's spleen to a trust confidant, and the opportunity to ask or offer favours. ${ }^{111}$ Their importance in communicating comfort and the idea of comfort is apparent from the keenness with which the absence of letters was sometimes felt. Sir Roger Newdigate expressed dismay and mock confusion at the lack of a letter from his wife, Sophia, who he referred to as Ba: 'I can't tell why I should have no letter from Bath today' he wrote on Lady Day 1773, 'Not Ba ill, that I won't believe - not Midge ill. I must have had a word then. No - it is the Post failed, it is the footman fail'd, some nonsense or other that vexes Ba too for my disappointment'.112 A generation later, Elizabeth Dryden 
was expressing similar feelings, her key source of emotional support and comfort coming from her correspondence with her sister-in-law, Mrs Steele. She habitually expressed gratitude for letters she received, noting on one occasion her 'thanks for your kind letter, they always do me good'.113 Given the greater distances and longer periods of absence that this engendered, letters were if anything even more important in Sweden. Elizabeth Dryden's contemporary, Dorotea Spens, ended a letter to her twin sister with a reminder to write back as soon as possible, as she was 'longing for the comfort of a letter', whilst Adolph Törneros asked his friend to 'write me a few lines to comfort me in my solitude'.114 Brita and Claes Julius Ekeblad also used their letters to share the everyday and to maintain an emotional bond, despite the distance that separated them. They create images for their loved one, telling each other about worries and joys: Claes Julius writes 'How happy you are to enjoy yourself in your boat, and to occupy yourself with whatever pleases you. When will I ever be as lucky? Never, I suspect'.115

\section{Conclusions}

What did comfort mean for country house owners such as Edward Leigh, Claes Julius Ekeblad, Elizabeth Dryden and the Spens family? How does it shape our understanding of the country house and elite domestic life in the late eighteenth and early nineteenth century, and what does this tell us about the geographical and cross-cultural spread of the idea of comfort?

Unsurprisingly, comfort meant physical well-being and particularly being warm; cold brought discomfort and discontent. This common need was addressed through the application of different technologies: more efficient grates in England and improved 
tiled stoves in Sweden. This distinction might be explained in terms of different climatic conditions, but the divide was cultural as well as environmental and reminds us of the need to recognise that any particular technological development was a matter of taste and cultural norms as well as technical possibilities. A similar point of connection yet distinction comes in the concern of country house owners with health and cleansing. Smoke was universally viewed as bad if it came from a fire (a well-recognised discomfort), but Swedish householders saw it more positively if it formed part of a process of fumigation, as we see with Brita Ekeblad's burning of juniper. More broadly, ideas of cleanliness and hygiene moved in parallel - a reflection of their importance to respectability and status as well as comfort. That said, it would be wrong to draw too firm a line between these ideas, as Elizabeth Dryden's search for a new house in London makes clear.

The imperative of marking status that this process demonstrates can be seen as a form of social comfort, but this was increasingly driven by the requirements of relaxed sociability and informality. The former can be seen in the houses of the Parisian elite in the early eighteenth century and in what Girouard terms the social house of early Georgian England; the latter came to prominence in the second half of the eighteenth century, when the search for informality lay at the heart of changes in the furnishing and organisation of domestic space. This was especially true in England; indeed, the admiration for 'English comfort' expressed by Erik Gustaf Geijer in the quotation with which we started our discussion can be seen as symptomatic of the spread of English ideas and English modes of living into continental Europe, including France. It is not always clear what this idealization comprised in the mind of the individual, and OdileBernez argues that it carried a veiled criticism of the French elite and their Anglomania. ${ }^{116}$ It is significant, though, that many of its material elements were to be 
found in the homes of Swedish nobles around the same time as they were becoming widespread in England. If country house owners in Sweden were emulating their English counterparts, they did so without much of a time lag and without leaving any trace of such motivation in their correspondence; the concerns, priorities and sentiments expressed by the Ekeblads and Spens and by Geijer are very to those voiced by Elizabeth Dryden and Roger Newdigate.

The letters written both in England and Sweden show us about how the elite of these two countries shared a taste for warm, airy, clean and, increasingly, informal houses. Yet what they underline over and again is the continued importance of older understandings of comfort as emotional support and solace. Physical comfort may have become more important to householders over the course of the eighteenth century, bringing with it a focus on materiality and the body; but this by no means erased a concern with people, inter-personal relationships and the spirit. Indeed, for many householders, including Claes Julius Ekeblad and Elizabeth Dryden, these concerns did much to define ideas of comfort and what is meant to be comfortable or uncomfortable. Family was especially important in this regard; their absence was compensated in part through material objects that acted as reminders of other places, people and times and gave meaning to rooms and the house, making it a home. A rounded perspective on comfort is therefore central to a thorough understanding of the relationship between material objects, the making of meaning and the country house as a lived space. However, absent family and friends were also brought into the home through writing and receiving letters. Correspondence brought comfort and its absence created distress and discomfort. Again, there is no indication of precedence; these were human emotions not mannered behaviours to be observed and emulated. 
Without denying the importance of material objects, we should recognize the importance of human interaction in creating the home and affording comfort. Home was a place for family and friends and a haven from the outside world. This is perhaps most clearly expressed in the lines that Claes Julius Ekeblad had carved over the main entrance at Stola: 'Friendship and peace reigns in this haven, which is the source of pleasure. Hate and worries reign in town, which is the source of sighs'.117 This juxtapositioning of the comforts of home with the cares of the outside world finds its echo in the sentiments expressed by Mrs Elton in Jane Austen's Emma when discussing the merits of public pleasures and the social round. 'Ah!', she exclaimed, 'there is nothing like staying at home, for real comfort'.118 For both English and Swedish elites, home was an escape from the cares of the world and place of emotional intimacy. Revealing these as shared feelings highlights the benefits of comparative analysis in testing the geographical specificities of comfort as a material and cultural construct. There was a broad confluence of attitudes to comfort across space and time; it was about people, friendship and contentment as much as warmth, easy chairs and designed informality. 


\section{Figure captions}

Figure 1. Tile stove model based upon the principle of Cronstedt and Wrede. Made out of masonry, usually brick, the stove burns much hotter than in a metal stove, it will radiate heat over a longer period and at a lower temperature. The firebox and heatexchange channels provides extra brick surface, which stores heat. A damper connects the stove to the chimney, and can be closed when the fire has burned out to help store heat. J. Cronstedt, 'Beskrifning på en inrättning af Kakelugnar til Weds Besparning' (Stockholm, 1767), courtesy of Umeå Universitetsbibliotek, Sweden.

Figure 2. Interior with Count Claes Julius Ekeblad and his wife Brita, nee Horn, Lorentz Svensson Sparrgren, 1783. Nationalmuseum, NM 1402. (Made available via Wikimedia Commons, 25371). 


\section{Notes}

${ }^{1}$ Alice Clark (ed.), Gleanings from an Old Portfolio Containing some Correspondence between Lady Louisa Stuart and her Sister, Caroline, Countess of Portarlengton and other Friends and Relatives, vol.2 (Edinburgh, 1895) - Letter from Lady Louisa Stuart to Lady Caroline Dawson, Countess of Portarlington, 2 November 1799, 281.

Quoted in J. Cornforth, English Interiors, 1799-1848: the Quest for Comfort (London, 1978), 13. ${ }^{2}$ Geijer, Erik Gustaf, Minnen. Utrag ur bref och dagböcker (Uppsala, 1834), 83, letter sent from Sidmouth, 1st June 1810. See also A. Blanck, Geijer I England 1809- 1810 (Stockholm, 1914) 63, 182-3, 238. (Geijer's letters to his family can be found in the Geijer-Hamilton collection; privately owned by family Stiernstedt, Uppsala.) ${ }^{3}$ Cornforth, English Interiors, op.cit., 209-12; J. Crowley, The Invention of Comfort. Sensibilities and Design in Early-Modern Britain and Early America (Baltimore, 2001).

${ }^{4}$ For fuller discussion of technological development in the country house, see: M. Girouard, Life in the English Country House (New Haven, 1978), 245-66; P.S. Barnwell and M. Palmer (eds), Country House Technology (2012); M. Palmer and I. West (eds), Technology in the Country House (Swindon, 2016).

${ }^{5}$ Crowley, op.cit., 147.

${ }^{6}$ P. Slack, The Invention of Improvement, (Oxford, 2015), 215-28; M. Odile-Bernez, 'Comfort, the acceptable face of luxury: an eighteenth-century etymology', The Journal for Early Modern Cultural Studies, 14:2 (2014), 3-21.

${ }^{7}$ Odile-Bernez, op.cit..

${ }^{8}$ Girouard, English Country House, op.cit., 213-44; Cornforth, English Interiors, op.cit., 11-14. 9 J. DeJean, The Age of Comfort. When Paris Discovered Casual and the Modern Home Began (New York, 2009). 
${ }^{10}$ Jane Austen, Sense and Sensibility (1811; The World's Classics edition, Oxford, 1970), 219. For a fuller discussion of this idealisation of the cottage, see A. Tinniswood, Life in the English Country Cottage (London, 1995), 104-33.

${ }^{11} \mathrm{~J}$. de Vries, Industrious Revolution. Consumer Behaviour and the Household Economy, 1650 to the Present (Cambridge, 2006), 44-5.

${ }^{12}$ See, for example: M. North, 'Fashion and luxury in eighteenth-century Germany', in J. Ilmakunnas and J. Stobart (eds) Taste for Luxury (London, 2017), 100-115; K. Fatsar, 'Enjoying country life to the full - only the English know how to do that!': appreciation of the British country house by Hungarian aristocratic travellers', in J. Stobart (ed.) Travel and the Country House (Manchester, forthcoming, 2017).

${ }^{13}$ Crowley, op.cit., 147.

${ }^{14}$ DeJean, op.cit., 18-19. She seems to misread the Bulls as commissioners, Devis as an artist, and the English conversation piece as a genre - see K. Retford, 'From the interior to interiority: the conversation piece in Georgian England', Design History, 20:4 (2007), 291-307.

${ }^{15}$ K.C. Phillipps, Jane Austen's English (London, 1970), 74-5; N. Page, The Language of Jane Austen (Oxford, 1972), 30, 38-9.

${ }^{16}$ See H. French and M. Rothery, Man's Estate: Landed Gentry Masculinities, 1660-1900 (Oxford, 2013), 191-5; A. Vickery, Behind Closed Doors. At Home in Georgian England (New Haven, 2009), $10,193-222$.

${ }_{17}$ M. Berg, 'Women's property and the industrial revolution', Journal of Interdisciplinary History, 24 (1993), 233-50.

18 For women, see J. Lewis, 'When a house is not a home: elite English women and the eighteenth-century country house', Journal of British Studies, 48:2 (2009), 336-63; Vickery, Behind Closed Doors, op.cit., 207-30. Men's emotional attachment to things is discussed in H. Metcalfe, 'The Social Experience of Bachelorhood in Late-Georgian England, c.1760-1830' (unpublished PhD thesis, University of Manchester, 2017), chapter 5; H. Chavasse, 'Material 
culture and the country house: fashion, comfort and lineage' (unpublished $\mathrm{PhD}$ thesis, University of Northampton, 2015), chapter 4.

19 W. Rybcynski, Home. A Short History of an Idea (New York, 1986).

${ }^{20}$ Odile-Bernez, op.cit., 13-15.

${ }^{21}$ For useful overviews, see P. Roebuck, Yorkshire Baronets, 1640-1760 (Oxford, 1980); J.

Beckett, The Aristocracy in England, 1660-1914 (Oxford, 1986); J. Habakkuk, Marriage, Debt and the Estate System: English Landownership 1650-1950 (Oxford, 1996);

22 On Swedish political history from a British perspective, see: M. Roberts The age of Liberty Sweden 1719- 1772 (Cambridge, 1986).

${ }^{23}$ M. Ågren, Domestic secrets. Women and property in Sweden, 1600- 1857 (Chapel Hill, 2009).

On Swedish Fideikomiss (a form of entail) see F. Bedoire, "Til sin Families Heder och

Conservation' eller 'Then flytande nyttan”, in B. I. Johansson \& C. Lovén (eds.) Byggnader och Betydelser: En Antologi om Arkitektur (Stockholm, 2000), 69-82.

24 J. Ilmakunnas, 'French fashions: aspects of elite lifestyle in eighteenth-century Sweden' in J. Ilmakunnas and J. Stobart (eds) Taste for Luxury (London, 2017), 243-63.

${ }^{25}$ Swedish Academy Dictionary, SAOB, saob.se, 'Komfort' (1936). See also E. Littré, Dictionnaire de la langue francaise, (1872-77); Odile-Bernez, op.cit., 16-17.

${ }^{26}$ Bekvämlighet can also be translated convenience or ease. Välbefinnande communicates a sense of well-being and health. Trivsam means pleasant, congenial, cosy and snug. Referring to a feeling skön can be translated pleasant, lovely and pretty, as well as comfortable.

${ }^{27}$ Also tilltalande, behaglig, angenäm. In German: Bequemlichkeit, behaglich, angenehm, gemütlich, schön; in French: Agreablé, plaisant, beau.

${ }^{28}$ Geijer, Minnen. op.cit., 40.

${ }^{29}$ Blanck, Geijer i England, op.cit., 229-30.

${ }^{30}$ In a dictionary from 1788 tröst and trösta is translated as comfort and to give comfort (to a crying child); to find solace in religion. G. Widegren, Ett Svenskt och Engelskt Lexicon, efter Kongl. Secreteraren Sahlstedts Svenska Ordbok (Stockholm, 1788). 
${ }^{31}$ For examples of complaints about cold, see J. Fowler and J. Cornforth, English Decoration in the Eighteenth Century (London, 1974), 225-6.

32 Richard Aldworth Griffin, second Lord Braybrooke, to Sir Stephen Glynne, 13 January 1812; quoted in Chavasse, op.cit., 141.

${ }^{33}$ Riksarkivet (RA), Stockholm; Ekebladska samlingen (ES), vol. 20, Letter from Brita Horn, 8 January 1777 . In $18^{\text {th }}$ century Sweden, most women (especially within nobility) still kept their maiden after marriage. This changed in the $19^{\text {th }}$ century. Brita signed all her letters Brita Horn. ${ }^{34}$ RA, ES/20, Brita Horn, 26 September 1777.

${ }^{35}$ James Gilray, 'The Comforts of a Rumford Stove', 1800 (Science and Society Picture Library, image 10315400); Charles Williams 'Luxury, or the Comforts of a Rumford Stove', 1801 (British Museum, 1935,0522.7.12). See also Crowley, op.cit., 187-90.

${ }^{36}$ The descriptions differ somewhat from those in the 1749 inventory, which generally refers to grates rather than stoves, but it is unclear whether this reflected new technology or a shift in language. See C. Gilbert and A. Wells-Cole, The Fashionable Fireplace, 1660-1840 (Leeds, 1985), 22.

${ }^{37}$ Northamptonshire Record Office (NRO), Northampton, Dryden of Canons Ashby, D(CA) 904, Schedule of furniture 1819.

38 A. Wilson, Comfort, Pleasure and Prestige: Country-House Technology in West Wales 1750-1930 (Leicester, 2016).

${ }^{39}$ C. J. Cronstedt, Beskrifning på ny inrättning af kakelugnar til weds besparning (Stockholm, 1767) E. Lundberg, Svensk bostad (Stockholm, 1942), 211. Stoves are found at Knole Park, Compton Place and Kedleston Hall. Sir John Griffin Griffin paid Abraham Buzaglo $£ 2$ 18s $6 \mathrm{~d}$ in 1779 for the 'Trial of a Stove in the Hall' at his London house, but does not appear to have proceeded to install stoves - see Chavasse, op.cit., 133-4.

${ }^{40}$ S. Scherman, Den Svenska Kakelugnen (Stockholm, 2007), 43. 
${ }^{41} \mathrm{~J}$. Ilmakunnas, 'To build according to one's status: a country house in late $18^{\text {th }}$-century Sweden', in J. Stobart and A. Hann (eds) The Country House: Material Culture and Consumption (Swindon, 2015), 40.

${ }^{42}$ Adolph Törneros and N. Afzelius (ed) Brev och dagboksanteckningar, I., 1810- 1825 (Stockholm, 1952), 54.

${ }^{43}$ M. Girouard, Life in the French Country House (London, 2000), 144-5.

${ }^{44}$ Quoted in Crowley, op.cit., 189.

${ }_{45}$ RA, ES/20, Brita Horn, 11 December 1777.

${ }^{46}$ RA, ES/20, Brita Horn, 25 October 1780.

${ }^{47}$ RA, ES/20, Brita Horn, 18 September 1779.

${ }^{48}$ RA, ES/20, Brita Horn, 1 November 1780.

${ }^{49}$ Arkiv digital (AD), Höja Säteri (HS) vol. 162, Letter, 26 September 1828. Carl Gustaf Spens to Jacob Melker Spens. www.arkivdigital.se, accessed 2016-11-24.

${ }^{50}$ NRO, D(CA)/361, Letter, 18 August 1816.

${ }^{51}$ NRO, D(CA)/361, Letter, 30 October 1820; [no date] November 1819.

52 B. Lemire, An education in comfort: Indian textiles and the remaking of English homes in the long eighteenth century', in J. Stobart and B. Blonde (eds) Selling Textiles in the Long Eighteenth Century. Comparative Perspectives from Western Europe (Basingstoke, 2014), 13-29. See also K. Ashenburg, The Dirt on Clean: an Unsanitised History (Toronto, 2007); B. van Bavel and O. Gelderblom, 'The economics of cleanliness in the Dutch Golden Age', Past and Present, 205 (2009), 41-69.

${ }^{53}$ NRO, D(CA)/361, Letter, 18 August 1816

${ }^{54}$ S. Pennell, 'Making the bed in later Stuart and Georgian England' in J. Stobart and B. Blonde (eds) Selling Textiles in the Long Eighteenth Century (Basingstoke, 2014), 38.

${ }^{55}$ RA, ES/20, Letter, Brita Horn, 8 September 1779.

${ }^{56}$ RA, ES/20, Letter, Brita Horn, 1 September 1779. 
57 D.M. Mitchell, 'Fine table linen in England 1450-1750: ownership and use of a luxury commodity', Unpublished PhD thesis, University of London, (1999); B. Lemire, op.cit., 13-29. ${ }^{58}$ NRO, D(CA)/361, Letter, 28 December 1816.

${ }^{59}$ For parallel processes of purification of pre-owned furniture, see R. Jones, “'Souvenirs of people who have come and gone": second-hand furnishings and the Anglo-India domestic interior, 1840-1920', in J. Stobart and I. Van Damme (eds), Modernity and the Second-hand Trade (Basingstoke, 2011), 111-38.

${ }^{60}$ H. Walpole, Horace Walpole Correspondence (New Haven, 1937-83), vol.10, 242. See also Odile-Bernez, op.cit., 15-16.

${ }^{61}$ Erik Gustaf Geijer \& H. Schück (ed) Svenska memoarer och bref, VII. (Stockholm, 1903), 108. Letter sent from Stoke Newington, 24 November 1809.

${ }^{62}$ Cornforth, English Interiors.

${ }^{63}$ NRO, D(CA) 904, 1819 inventory.

${ }^{64}$ DeJean, op.cit., 131-9, 144-64.

${ }^{65}$ Shakespeare Central Library and Archives (SCLA), Stratford-upon-Avon, Leighs of Stoneleigh Abbey, DR18/4/43, 1774 Inventory with 1806 annotations; DR18/4/69, 1786 inventory. See also J. Stobart and M. Rothery, 'Fashion, heritance and family: new and old in the Georgian country house', Cultural and Social History, 11:3 (2014), 385-406

${ }^{66}$ Girouard, English Country House, op.cit., 234-9; Vickery, Behind Closed Doors, op.cit., 129-65.

${ }^{67}$ Lundberg, Svensk bostad, 215-22. F. Bedoir, Den svenska arkitekturens historia, 1000-1800

(Stockholm, 2015); Kungliga biblioteket (KB), Swedish Royal Library, Ekeblad EP.E.6 vol. 1 \& 2, Letter, CJ Ekeblad, 7 April 1788

${ }^{68}$ RA, ES/20, Letter, Brita Horn, 14 December 1776.

${ }^{69}$ KB, EP.E.6 vol. 1 \& 2, Letter, CJ Ekeblad, 24 April 1788.

${ }^{70}$ B. Westrin, Stola säteri, (Nossebro, 1986), 18-9, 32.

${ }^{71}$ RA, Ekebladska samlingen, vol. 25, 'Inventarium öfwer all befintlelig lös egendom [... ] Stola, Lindholmen, Järneväg och Sahl 1801', (inventory of all existing movable property...). 
72 D. Gerhold, 'London's suburban villas and mansions, 1660-1830', The London Journal, 34:3 (2009), 233-63.

73 Törneros, Brev op.cit., 46-7. (September 1822) 'beqvämligt lugn'.

74 Törneros, Brev, op.cit., 48-9.

75 Törneros, Brev, op.cit., 47.

76 J. Cornforth, Early Georgian Interiors (New Haven, 2004), 11-74. See also Girouard, English Country House, op.cit., 154-60, 199-205, 239.

77 Stobart and Rothery, 'Fashion, inheritance and family', op.cit.

${ }^{78}$ See: G. Tyack, 'Stoneleigh Abbey in the nineteenth century', in R. Bearman (ed.), Stoneleigh Abbey: The House, Its Owners, Its Lands (Stratford, 2004), 120-25.

${ }^{79}$ Bedoir, Svenska arkitekturens, 412-13.

${ }^{80}$ Adolph Törneros and N. Afzelius (ed.), Brev och dagboksanteckningar, II, brev 1826-1829 (Stockholm, 1952), 19 Aug. 1826

${ }^{81}$ NRO, D(CA)/361, Letter, 8 January 1819; 2 June 1819; [no date] November 1819.

82 H. Greig, The Beau Monde (Oxford, 2013), 37-45.

${ }^{83}$ NRO, D(CA)/361, Letters, [no date] October 1819, [no date] November 1819.

${ }^{84}$ For fuller discussion, see Roberts Age of Liberty, 15-58, 176-84.

${ }^{85}$ NRO, D(CA)/361, Letter, 2 June 1819.

${ }^{86} \mathrm{C}$. Campbell, "The desire for the new: its nature and social location as presented in theories of fashion ad modern consumerism', in R. Silverman and E. Hirsch (eds), Consuming Technologies: Media and Information in Domestic Spaces (London, 1992), 93-105.

${ }^{87}$ NRO, D(CA)/361, Letter, 28 January 1814.

${ }^{88}$ See J. Stobart and M. Rothery, Consumption and the Country House (Oxford, 2016), chapter 5. ${ }^{89}$ See French and Rothery, Man's Estate, 185-234.

${ }^{90}$ NRO, D(CA)/361, Letter, 20 October 1814.

${ }^{91}$ Warwickshire Record Office: Warwick, Newdigate of Arbury Hall, CR136/B/2014, Letter, 29 April 1795. 
${ }_{92}$ West Yorkshire Archive Service: Calderdale, SH7/RL/150, Anne Lister to her brother, Rev John Lister, 25 April 1749.

${ }^{93}$ SCLA, DR672/59, letter from Elizabeth, Lady Chandos, 30 September 1682; DR672/58, letter from Elizabeth Brydges to Mary Brydges, 15 August 1682.

${ }^{94}$ AD, HS,/262, Letter, Dorothea Cronacker-Spens to Gustava Cronacker-Spens, 31 Aug 1827.

'...det är en sådan tröst att ha honom hemma...'

${ }^{95}$ AD, HS/262, Letter, Louise Cronacker to her daughter Gustava Cronacker-Spens 8 Feb. 1823.

96 KB, EP.E.6 vol. 1 \& 2, Letter, CJ Ekeblad 21 April 1788.

${ }_{97}$ RA, ES/20, Letter, B Horn 30 November 1776.

${ }^{98}$ KB, EP.E.6 vol. 1 \& 2, Letter, CJ Ekeblad, 15 September 1783.

${ }^{99}$ Lewis, op.cit.; Vickery, Behind Closed Doors, op.cit., 207-30.

100 Lewis, op.cit., 361

${ }^{101}$ SCLA, 18/4/59, 1806 inventory.

102 RA, ES/20, Letter, B Horn, 27 November 1780.

${ }^{103}$ See K. Harvey, The Little Republic: Masculinity and Domestic Authority in Eighteenth-Century Britain (Oxford, 2012), 139-50, for a discussion of similar practices amongst the middling sort. ${ }^{104}$ K. Smith, 'Imperial Families: women writing home in Georgian Britain', Women's History Review, 24 (2015), 843-60.

105 NRO, D(CA)903b, Letter, 13 January 1817.

106 NRO, D(CA)903b, Letter, 13 January 1817.

${ }^{107}$ A. Epp and L. Price, 'The storied life of singularized objects: forces of agency and network transformation', Journal of Consumer Research, 36 (2010), 820-37.

108 NRO, D(CA)904, Schedule of furniture, 1819.

${ }^{109}$ NRO, D(CA)361, Letter, 29 October 1822.

110 RA, ES/20, Letter, B. Horn, 1 February 1786.

111 For fuller discussion of the role of letters in articulating social worlds, see: S. Whyman Sociability and Power in Late-Stuart England: the Cultural Worlds of the Verneys 1660-1720 
(Oxford, 1999); R. Earle (Ed.) Epistolary Selves: Letters and Letter-writers, 1600-1945

(Aldershot, 1999); C. Brant, Eighteenth-Century Letters and British Culture (Basingstoke, 2006);

Smith, op.cit.

112 WRO, CR136/B/4046/e, Letter, 25 March 1773.

113 NRO, D(CA)/361, Letter, 29 October 1822.

${ }^{114}$ AD, HS/262, Letter Dorothea Cronacker-Spens to Gustava Cronacker-Spens, 31 Aug 1827;

Törneros, Brev, II, op.cit., 120. 12 Dec. 1826, '... några rader till min tröst i ensligheten.'

115 KB, EP.E.6 vol. 1 \& 2, Letter, CJ Ekeblad, September 151783.

116 See Odile-Bernez, op.cit., 16-17.

117 B. Westin (1986) 18. 'L'amitié et la paix reignent dans cet acile et sont la source de plaisirs.

Le thumulte et la haine reignent dans les villes et sont la source des soupirs'.

118 J. Austen, Emma (1815; London, Penguin edition, 1985), 277. 